\title{
MEASURING SATISFACTION AND EXPERIENCED SENTIMENTS OF WEBSITE USERS WHEN EXPLORING CROATIAN GASTRONOMIC TOURIST OFFER
}

\author{
Slobodan Ivanović \\ Angela Milenkovska Klimoska \\ Vedran Milojica
}

https://doi.org/10.20867/tosee.05.20

\begin{abstract}
Purpose - this paper presents the importance and necessity of measuring satisfaction of website users with the texts presenting the Croatian gastronomic offer, and their experienced sentiments during and after browsing. The goal is to determine the influence of these texts on successful decision-making process when choosing Croatia as a gastronomic holiday destination.

Methodology - the empirical research was done in February 2019 using a structured questionnaire which was distributed online. The acquired data was analyzed using the SPSS 21 Statistical package. The authors used Cronbach Alpha Coefficient to test the questionnaire validity, as well as Pearson's Coefficient of Correlation, and T-Test and Levene's Test for Equality for variances. Findings - By using Pearson's Coefficient of Correlation a positive correlation had been determined indicating that the growth of satisfaction of website users with the texts will result in experiencing positive sentiments towards Croatia as destination. No that no statistically significant difference has been determined for satisfaction in relation to their monthly income. By using Ttest and Levene's Test for Equality of Variances a statistically significant difference for sentiments has been determing in relation to the respondent's gender. A a statistically significant difference has been determined for positive sentiments in relation to the respondent's gender, which was not the case for satisfaction and gender.

Contribution - The results enable better understanding of where to focus in text improvements (its quality, diversity, etc.). The main goal has to be better success in tourist offer promotion, and positive decision when choosing Croatia as a holiday destination.
\end{abstract}

Keywords gastronomy, websites, gastronomic offer, Croatia, measuring satisfaction, measuring sentiments

\section{INTRODUCTION}

Tourism became a major and significant part of a contemporary experience economy within which food plays an important and significant role. Food represents a crucial part of all cultures, a major element of global intangible heritage of a destination and increasingly important attraction for tourists. Strong and firm connection between food and tourism represents a platform which contributes significantly towards successful local economic development of a destination, and enables the potential of development and/or strengthening of a destination's brand. Over the years tourist's preferences have significantly changed from the classical tendency to visit physical sights such as museums and monuments towards; the imperative is now placed on new experiences in 
ToSEE - Tourism in Southern and Eastern Europe, Vol. 5, pp. 335-348, 2019

S. Ivanović, A. Milenkovska Klimoska, V. Milojica: MEASURING SATISFACTION AND

the sense of consuming intangible elements of culture (atmosphere, creativity and lifestyle), which provides new opportunities for tourism destinations and its inhabitants, but at the same time creates major and new challenges especially when discussing development of new and unique experiences, undertaking marketing activities, and formation of a recognizable brand (Richards in OECD, 2012). Over the years development of digital economy left a strong impact on tourism industry in many ways, but one of them that left a strong positive impact on the business was easier and more efficient presentation and promotion of tourist offer (Pilepić et. al, 2010), which is of significant importance for Gastronomic tourism. When presenting and promoting Gastronomic tourist offer, all the information (text in particular) need to be precise and up-to-date in the sense that tourists need to be completely aware of all the specificities of a certain gastronomic offer, considering that any specific detail can prevail when deciding which destination to choose for a holiday. Texts need to present the gastronomic offer in a way that the cultural essence is presented aiming towards waking positive sentiments towards the offer and the destination in general, which would hopefully contribute towards choosing that particular destination. The only way to determine the level of efficiency of a certain website is through measuring the level of satisfaction with the text contents, and experienced sentiments after browsing them. The determined results can contribute towards future website contents improvement, which will stimulate destination's positive performance, improve the promotion on the tourist market, as well as its competitive positioning. The main purpose of this paper is to determine the level of satisfaction and which sentiments do website users experience when browsing the textual contents about Croatian gastronomic tourist offer. After the theoretical part of the paper the authors will present the applied methodology and results of the empirical research. Based on the results the authors will propose developing guidelines. Finally, the conclusion will summarize all the determined results.

\section{THEORETICAL BACKGROUND}

\subsection{The importance of Internet and Websites as presenters of contemporary tourist offer}

The data from the Oxford Economics (2016) and Tourism Economics (2016) indicate that almost half of the global population, which amounts over 3 billion of people currently uses the internet. Approximately 1,5 billion started using it since 2008 towards, and the growth rate is rising. Within this, the European Union is a relatively mature regional market, in particular due to the fact that from approximately 600 million Europeans who are online, 400 million of them come from the EU member states. In the majority of the EU countries the proportion of population online amounts over $75 \%$, which makes Europe the leader on world level from this point of view. Internet plays a vital and growing role in the European Tourism and Hospitality Industry, which has been witnessed by large and significant increases and improvements in online access throughout the European region allowing greater online sales and research in the tourism sector. Increase of Internet access made a significant impact on tourism development by contributing towards global connectivity. Internet became a highly trusted source of information, and overall impact of online content presented on websites includes the impact of online tourism sales, and trips researched online. Today various forms of online 
ToSEE - Tourism in Southern and Eastern Europe, Vol. 5, pp. 335-348, 2019

S. Ivanović, A. Milenkovska Klimoska, V. Milojica: MEASURING SATISFACTION AND ...

content are far more trusted in comparison to the traditional media and recommendations from friends and relatives. Clear and accessible information are sought on daily basis, and their quality and diversity significantly contributes towards achieving destination competitiveness and tourism performance. Becoming incredibly significant in communication between tourist offer carriers and (potential) tourists resulted in websites becoming a focus of numerous scientific researches in the world. In order to determine the current achievements in tourism website evaluation methods, Law et al. (2010) conducted a thorough analysis of most significant published scientific achievements in that area in the period from 1996 until 2009 and determined that only a limited number of researches was made until then in the field of tourism website evaluation, and those using previously mentioned approaches resulted with a moderate success. Their opinion was that the approaches used in that period were maybe inadequate for determining what motivates users to browse the website contents and make purchases; consumers and practitioners are insufficiently familiar with how website performance can be precisely measured, since in that period of time current tourism literature had no common agreement in terms of standards or techniques how websites should be evaluated. They proposed that future research should be aimed towards formation of specific standards for tourism website evaluation, as well as development of new research techniques focused on determining the needs of consumers and practitioners, especially when taking into consideration continuous changes in tourist behavior. In the following years new researches were made. Dickinger and Stangl (2013) proposed a theoretically-based alternative, a formative measurement approach for website performance. They formed a formative index which enables for organizations to conduct an evaluation of their websites and determining the impact of performance of their website on overall value and satisfaction of website users. RuelNovabos et al (2015) developed a User-Perceived Quality tool using an integrated set of website quality attributes from the already existing tools for the destination websites evaluation in order to help their local government units in determining their websites effectiveness. The tool also informs web developers of design deficiencies that they need to improve. Its application contributes towards increasing the effectiveness of destination websites, in terms of determining how these websites are perceived by target users, respectively (potential) tourists.

Today it is insufficient to just develop a website in order to become and/or remain competitive on the e-marketspace. The website dimensions need to be developed according to the type of the website stakeholder, their characteristics, marketing goals and issues of a website, as well as type and profile of a website user (Sigala, 2011), and their effectiveness and efficiency needs to be determined through measuring the website user's level of satisfaction and sentiments experienced when browsing the texts.

\subsection{Measuring satisfaction of website users in Tourism}

Over the years measuring satisfaction became one of the central concepts when monitoring and studying behavior of tourists (i.e. Kozak and Rimmington, 2000; Kozak, 2001; Kozak et al, 2005; Maditinos, 2008; Avelini Holjevac et al, 2009; Marković et al, 2010; Correia et al, 2013; Marković et al, 2014; Lončarić et al, 2015, etc.). One of the biggest challenges with which tourist destinations are faced today is the formation of a tourist offer which will be able to satisfy the desires and needs of current and potential tourists as much as possible. Today tourists are becoming increasingly more demanding, as a result of development of certain activities, experiences, knowing their rights coming 
ToSEE - Tourism in Southern and Eastern Europe, Vol. 5, pp. 335-348, 2019

S. Ivanović, A. Milenkovska Klimoska, V. Milojica: MEASURING SATISFACTION AND

from the relation seller-buyer. They demand "Value for money", respectively they expect to achieve higher value for themselves. Along with the quality of tourist products and services, tourist satisfaction represents one of the basic factors in achieving competitiveness of a tourist destination on the contemporary tourist market. The basic strategy of a destination aimed achieving success is precise measuring and monitoring tourist's level of satisfaction in order to determine their attitudes towards tourist offer elements and destination in general (Marković et al, 2010). As previously mentioned, today tourists tend to choose to find out details about a specific destination and its offer online, which made it necessary to pay additional attention towards determining their level of satisfaction with the websites presenting the tourist offer. This is witnessed by the researches presented following. Subramonian et al (2014) focused on investigating the factors of e-satisfaction with online travel services and describe the connection with the analyzed factors. Their results determined that the factors of e-satisfaction had a significant role in traveler's satisfaction with the online tourism products. Also, it has been determined that the model proposed by the authors is reliable and can significantly help practitioners managing travel and tourism online businesses, considering that it identifies all the important factors for e-satisfaction related to tourism products and services, and can make significantly easier for the practitioners to understand tourist's interactions with tourism products and services. Noronha and Rao (2017) aimed their research towards understanding the effect of website quality on customer satisfaction and their purchase intention after browsing the online travel ticket booking websites. They determined that the strongest quality factors in this case were quality of information provided, system quality, quality of services and website design. Determined results are of significant use for the companies selling these services considering that it enables determining which factors are currently contributing towards positive business result, and which factors are critical and need further actions. The main goal must be constant provision of top quality services and retaining of current service users, as well as attracting new ones. Masa'deh's et al. (2017) research examined the interconnection among the knowledge quality, system quality, quality of service, perceived ease of use, satisfaction of website users and their continuous intention towards using the tourist board website. The results indicated that a positive effect of quality of knowledge and website user's satisfaction was achieved through use of the website and its content.

\subsection{The importance of determining Tourist's Sentiments}

Previously, when thinking about buying a certain product or a service, people would ask their friends and family, or acquaintances for their opinion. However, this has changed significantly over the years, with the development of Internet and Information Technology, in particular in tourism industry. Today tourists are enabled to express their own opinions, feelings and experiences about tourist products and services online, as well as find out more about other people's experiences (Agarwal, 2015; Agarwal and Mittal, 2014a; Agarwal and Mittal, 2014b), or they can simply choose to browse the general information about a tourist destination's offer. If taken into consideration that today's tourism websites are capable to present the destination's tourist offer to the very details, it can be justifiably stated that tourist's exposure to the website text contents will result in forming hopefully positive sentiments towards a destination and its offer (Ivanović and Milojica, 2018). Measuring sentiments, in tourism in particular, has been given a significant attention over the years, in which the emphasis is made mostly on 
ToSEE - Tourism in Southern and Eastern Europe, Vol. 5, pp. 335-348, 2019

S. Ivanović, A. Milenkovska Klimoska, V. Milojica: MEASURING SATISFACTION AND

textual contents analysis (such as blogs, reviews, etc.) (i.e. Rahmani et al, 2018; Liu et al, 2019; Yan et al, 2018; Gräbner et al, 2012) or determining their attitudes by either using questionnaires or being interviewed (Ivanović and Milojica, 2018; Hosany, 2012; Gnoth et al 2000; Servidio and Rufolo, 2016; Hosany et al, 2014; Hosany and Gilbert, 2009) etc. In order to get a clearer insight the authors will present some of them. I.e., Prayag et al (2015) focused primarily in their paper on determining the relationships among specific emotional responses and perceived overall image, perceived overall image and tourist satisfaction, perceived overall image and intention to recommend, specific emotional responses and tourist satisfaction and tourist satisfaction and intention to recommend. Their results were especially significant for development of further marketing activities, since they determined that tourist's experienced emotions have a positive effect on their evaluation of destination's overall image as well as their experienced level of satisfaction. These findings are exceptionally important for future marketing activities which need to be aimed towards formation of an appropriate image based on emotions caused by the tourist destination. Within their study Hosany and Gilbert (2009) managed to develop a scale aimed towards measuring tourists' emotional responses toward destinations. They managed to prove empirically the direct connection among the dimensions of experienced tourist's emotions, their level of satisfaction as well as future intention to recommend, as well as that satisfaction is a mediator between tourist's emotions and intentions to recommend.

Previously presented theoretical background presents the most important findings in the areas of Information Technology, measuring website user's satisfaction with the websites, and measuring sentiments in tourism. It is quite clear that the importance of measuring satisfaction with the websites has been recognized as one of the most important pre-conditions for its further improvements; website user's opinions and attitudes need to be monitored constantly in order to determine all the website's advantages, and where potential improvements are necessary. Particular attention needs to be made on forming and placing professionally prepared textual contents presenting the tourist offer in a professional, yet warm and pleasant way that will stimulate website user's positive sentiments, and make them feel invited and welcome. In order to determine the success of these texts, it is important to measure the website user's sentiments as well through use of specifically structured questionnaires. According to the knowledge of authors of this paper, the majority of research aimed in analyzing sentiments is based on the analysis of texts with the use of various software. However, practically no research was focused on determining the website user's satisfaction with the actual texts presenting the tourist offer nor their experienced sentiments after browsing them, which is the main reason of the authors for undertaking this study. It is expected that the results of this research will contribute significantly towards improvement and formation of better quality texts which will manifest on formation and implementation of more successful marketing strategies, all with a goal of achieving competitiveness on the tourist market. 
ToSEE - Tourism in Southern and Eastern Europe, Vol. 5, pp. 335-348, 2019

S. Ivanović, A. Milenkovska Klimoska, V. Milojica: MEASURING SATISFACTION AND ...

\section{METHODOLOGY}

An empirical research was conducted with the use of a structured questionnaire, which was filled online by the respondents who browsed the text presenting the gastronomic offer of the Republic of Croatia. The respondents were asked to visit the official website of the Croatian Tourist Board and search the text contents which present Croatian gastronomic offer, and following to fill the questionnaire through the website EnKlik anketa. The questionnaire was distributed in January 2019 through e-mail and social networks, and 90 respondents participated successfully in the survey by answering on all the questions given. The authors measured their level of satisfaction and experienced sentiments by using the methods of Descriptive Statistics (Arithmetic Mean and Standard Deviation, Pearson's Coefficient of Correlation, T-test and Levene's Test for Equality of Variances. The questionnaire was prepared according to the Ivanović and Milojica, 2018; Roblek et al (2018), Lapidus and Bond-Dryankova (2014), Holtgräfe and Zentes (2012), Pereira et al. (2017), Montoya-Weiss et al. (2003), Foukis (2015), Yoo and Donthu (2001), Ho and Lee (2007), Maxham (2002a, 2002b, 2003), Ho and Lee (2007), Hasan and Abuelrub (2011), Lin (2007) and Tsai (2017) when measuring the level of satisfaction, and Ivanović and Milojica, 2018, Roblek et al (2018), Lapidus and BondDryankova (2014), Holtgräfe and Zentes (2012), Pereira et al. (2017), Montoya-Weiss et al. (2003), Foukis (2015), Yoo and Donthu (2001), and Maxham (2002a, 2002b, 2003) when measuring sentiments.

The authors formed and tested the following hypotheses:

H1: Satisfaction of website users with the texts presenting the Croatian gastronomic offer is significantly connected with formation of positive sentiments towards Croatia as a tourist destination.

$\mathrm{H} 2$ : There is a significant difference among male and female respondents in terms of expressing high level of satisfaction with the texts presenting Croatian gastronomic offer.

H3: There is a significant difference among male and female respondents in terms of expressing positive sentiments with the texts presenting Croatian gastronomic offer.

H4: Respondents with higher monthly income will express higher level of satisfaction after browsing the texts than those with a lower income.

\section{FINDINGS}

The following table presents the measuring the reliability of the questionnaire.

Table 1: Monitored scales in the questionnaire

\begin{tabular}{|l|c|c|}
\hline \multicolumn{1}{|c|}{ Questions } & Cronbach's Alpha & N of Items \\
\hline Satisfaction with the Texts & 0.879 & 8 \\
\hline Sentiments & 0.948 & 13 \\
\hline
\end{tabular}

Source: Author's analysis 
ToSEE - Tourism in Southern and Eastern Europe, Vol. 5, pp. 335-348, 2019

S. Ivanović, A. Milenkovska Klimoska, V. Milojica: MEASURING SATISFACTION AND

It is visible from the previous table that the Cronbach's Alpha Coefficient is quite high for all the scales, amounting significantly more than 0.7 representing a high level of reliability, which points to the very high reliability and the possibility for formation of a unique result for all the mentioned scales. The results for the socio-demographic characteristics are the following. According to gender, $45.6 \%$ respondents were male, and $54.4 \%$ female. In terms of age group, the majority of respondents belonged to the age group up to $25(45.6 \%)$, followed by 36-40 (15.6\%), 26-30 (13.3\%), and 31-35 (12.2\%). The majority of the respondents were from Bosnia and Herzegovina (18.9\%), followed by Croatia (16.7\%) and Serbia (13.3\%). Other respondents were from other states (20 from the United Kingdom, 4 from Poland, 2 from Romania and Hungary, and 1 from Bulgaria, Finland, France, Hong Kong, Korea, Lithuania and the Republic of Korea). In terms of employment status, $54.4 \%$ responded that they work for wages, $37.8 \%$ were students, $4.4 \%$ self-employed, $2.2 \%$ unemployed and searching for work, and $1.1 \%$ retired. In terms of monthly income, the majority of respondents stated they have up to 500.00 EUR (40.0\%). 501.00€ to $1.000 €(24.4 \%)$ and $1.001 €-1.500 €(22.2 \%)$. The majority of respondents are highly educated, respectively $42.2 \%$ have a bachelor's degree, followed by master's degree (32.2\%), 20.0\% doctorate, while only $5.6 \%$ have a secondary school, 4-year program. Following the authors will present the respondent's level of satisfaction with the texts presenting the Croatian gastronomic offer, as well as which sentiments they experienced after browsing these texts.

Table 2: Satisfaction with the texts presenting the Croatian gastronomic tourist offer

\begin{tabular}{|l|r|r|}
\hline Elements & \multicolumn{1}{|c|}{ X } & \multicolumn{1}{|c|}{ SD } \\
\hline $\begin{array}{l}\text { Quality of text presenting gastronomic offer to the point that it stimulates me } \\
\text { to visit Croatia }\end{array}$ & 3.39 & .71 \\
\hline $\begin{array}{l}\text { Diversity of text presenting gastronomic offer to the point that it stimulates } \\
\text { me to visit Croatia }\end{array}$ & 3.27 & .75 \\
\hline $\begin{array}{l}\text { Text about the gastronomic tourist offer present its characteristics in great } \\
\text { details }\end{array}$ & 3.46 & .82 \\
\hline Website text contents presenting gastronomic offer are up-to-date & 3.38 & .84 \\
\hline $\begin{array}{l}\text { Website text contents presenting gastronomic offer are offered to diverse } \\
\text { foreign languages }\end{array}$ & 3.31 & 1.02 \\
\hline Text font makes the text very understandable & 3.51 & .86 \\
\hline Color of the text does not influence the comprehension of a text & 3.41 & .92 \\
\hline Text about the gastronomic tourist offer are very useful & 3.68 & .80 \\
\hline
\end{tabular}

Source: Author's analysis

Previous table presents the website user's satisfaction with the texts presenting the Croatian gastronomic offer. The highest grade was given to the usefullness of texts $(\overline{\mathrm{x}}$ 3.68 and SD 0.80), followed by the influence of text font on understandibility of text $(\overline{\mathrm{x}}$ 3.51 and SD 0.86), and text's ability to present gastronomic offer in great details ( $\bar{x} 3.46$ and SD 0.82). A bit lower grade was given to the statements of non-influence of text color on the text comprehension ( $\bar{x} 3.41$ and SD 0.92), influence of text quality on stimulating website users to visit Croatia $\bar{x} 3.39$ and SD 0.71) and text contents being upto-date ( $\bar{x} 3.38$ and SD 0.84 ). The lowest grade was given to the text contents being offered in foreign languages $(\bar{x} 3.31$ and SD 0.75$)$ and the influence of diversity of texts on stimulating website users to visit Croatia $(\overline{\mathrm{x}} 3.27$ and SD 0.75$)$. 
ToSEE - Tourism in Southern and Eastern Europe, Vol. 5, pp. 335-348, 2019

S. Ivanović, A. Milenkovska Klimoska, V. Milojica: MEASURING SATISFACTION AND ...

Table 3: Experienced sentiments after browsing the texts presenting the Croatian gastronomic tourist offer

\begin{tabular}{|l|c|r|}
\hline Elements & $\overline{\mathrm{x}}$ & $\mathrm{SD}$ \\
\hline $\begin{array}{l}\text { Browsed texts on a website presenting gastronomic offer awake positive } \\
\text { sentiments in me when thinking about visiting Croatia as a tourist destination in } \\
\text { general }\end{array}$ & 3.58 & .81 \\
\hline $\begin{array}{l}\text { Browsed texts on a website presenting gastronomic offer awake positive } \\
\text { sentiments in me when deciding on visiting Croatia as a tourist destination in } \\
\text { general }\end{array}$ & 3.59 & .73 \\
\hline $\begin{array}{l}\text { Information on the website related to the gastronomic tourism offer motivates } \\
\text { me to visit Croatia and experience the offer personally }\end{array}$ & 3.54 & .80 \\
\hline $\begin{array}{l}\text { I am completely satisfied with the quality of the information about the } \\
\text { gastronomic tourism offer on the website }\end{array}$ & $\mathbf{3 . 4 2}$ & .85 \\
\hline $\begin{array}{l}\text { I am completely satisfied with the reliability of information about gastronomic } \\
\text { tourism offer on the website }\end{array}$ & 3.46 & .88 \\
\hline $\begin{array}{l}\text { I am completely satisfied with the diversity of information about the gastronomic } \\
\text { tourism offer on the website }\end{array}$ & 3.46 & .85 \\
\hline $\begin{array}{l}\text { Design and layout of the website where the text is placed significantly } \\
\text { contributes towards experiencing my positive sentiments when browsing }\end{array}$ & 3.60 & .79 \\
\hline $\begin{array}{l}\text { Browsing the website text contents searching for gastronomic tourist offer } \\
\text { description was worth the effort }\end{array}$ & 3.48 & .82 \\
\hline $\begin{array}{l}\text { The quality of the information about gastronomic tourism on the website satisfies } \\
\text { my needs to the extent that I will use this website in the future }\end{array}$ & 3.54 & .80 \\
\hline $\begin{array}{l}\text { The diversity of the information about gastronomic tourism on the website } \\
\text { satisfies my needs to the extent that I will use this website in the future }\end{array}$ & 3.56 & .72 \\
\hline It is very likely that I will spread positive word of mouth about this website & 3.54 & .86 \\
\hline $\begin{array}{l}\text { I would recommend this website to my friends who are in search of the } \\
\text { gastronomic tourism information }\end{array}$ & $\mathbf{3 . 6 3}$ & .91 \\
\hline $\begin{array}{l}\text { The information on the website made me imagine in my mind the true authencity } \\
\text { of the gastronomic tourist offer to the point that I would like to experience it } \\
\text { personally }\end{array}$ & $\mathbf{3 . 6 2}$ & .82 \\
\hline
\end{tabular}

Source: Author's analysis

Results in the previous table indicate that respondents show positive sentiments after browsing the texts presenting gastronomic offer. The highest grade has been given to the element of future recommendation to friends in search of information $(\overline{\mathrm{x}} 3.63$ and SD 0.91), followed by the possibility of imagining the true authencity of the gastronomic offer to the point that the website users would be interested in experiencing it personally ( $\overline{\mathrm{x}} 3.62$ and SD 0.82), significance of website's design and layout in experiencing positive sentiments ( $\overline{\mathrm{x}} 3.60$ and SD 0.79 ), text information stimulating positive sentiments when deciding to visit Croatia as a destination in general ( $\bar{x} 3.59$ and SD $0.73)$, the influence of text diversity on future use of the website ( $\bar{x} 3.56$ and SD 0.72), the potential of future positive word of mouth about the website ( $\bar{x} 3.54$ and SD 0.86), influence of information quality on future use of website and influence of website information on visiting Croatia and experiencing the offer personally ( $\bar{x} 3.54$ and SD $0.80)$. A bit lower grade was given to the following elements: browsing texts being worth the effort ( $\overline{\mathrm{x}} 3.48$ and SD 0.82), complete satisfaction with the reliability with the information ( $\overline{\mathrm{x}} 3.46$ and SD 0.88$)$ and diversity of information $(\overline{\mathrm{x}} 3.46$ and SD 0.85$)$, 
ToSEE - Tourism in Southern and Eastern Europe, Vol. 5, pp. 335-348, 2019

S. Ivanović, A. Milenkovska Klimoska, V. Milojica: MEASURING SATISFACTION AND

while the lowest grade was given to the complete satisfaction with the text quality $(\overline{\mathrm{x}}$ 3.42 and SD 0.85)

The following table will present the Pearson's Coefficient of Correlation which was used in order to determine the connection among satisfaction and experienced sentiments of websites who were in search of information about the Croatian gastronomic offer.

Table 4: Pearson's Coefficient of Correlation

\begin{tabular}{|c|c|c|c|c|}
\hline & & $\begin{array}{c}\text { Satisfaction with the } \\
\text { Texts }\end{array}$ & Sentiments & Monthly Income \\
\hline \multirow{3}{*}{$\begin{array}{l}\text { Satisfaction with the } \\
\text { Texts }\end{array}$} & $\mathrm{r}$ & 1 & $.707^{* * *}$ & -.004 \\
\hline & $\mathrm{p}$ & & .000 & .971 \\
\hline & $\mathrm{N}$ & & 90 & 90 \\
\hline \multirow{3}{*}{ Sentiments } & $\mathrm{r}$ & & 1 & .132 \\
\hline & $\mathrm{p}$ & & & .214 \\
\hline & $\mathrm{N}$ & & & 90 \\
\hline \multirow{3}{*}{$\begin{array}{l}\text { Monthly income } \\
\text { (in EUROS) }\end{array}$} & $\mathrm{r}$ & & & 1 \\
\hline & $\mathrm{p}$ & & & \\
\hline & $\mathrm{N}$ & & & 90 \\
\hline
\end{tabular}

**. Correlation is significant at the 0.01 level (2-tailed)

*. Correlation is significant at the 0.05 level (2-tailed).

Source: Author's analysis

The results from the previous table indicate that the level of correlation among the satisfaction with the texts and experienced sentiments is of medium intensity ( $\mathrm{r}=0.707$; $\mathrm{p}<0.01$ ), due to which it is possible to conclude that website users who experience higher level of satisfaction will more likely form positive sentiments towards Croatia as a tourist destination, which may be considered as one of the crucial factors in a decision-making process when choosing a holiday destination. Hypothesis 1 has been confirmed. By testing the hypothesis 4 the authors wanted to test the potential connection among the respondents according to their level of monthly income achieved and experienced sentiments after browsing the information about the gastronomic tourist offer. The determined results $(r<0.3 ; p>0.01)$ indicate no significant connection with the sentiments nor satisfaction due to which the hypothesis 4 is rejected. The following table presents the results for t-test for all the observed factors in the research according to the gender.

\section{Table 5: Group Statistics}

\begin{tabular}{|l|c|c|c|r|r|}
\hline & Gender & $\mathrm{N}$ & Mean & Std. Deviation & \multicolumn{1}{|c|}{ Std. Error Mean } \\
\hline \multirow{2}{*}{$\begin{array}{l}\text { Satisfaction with the } \\
\text { Texts }\end{array}$} & Male & 41 & 3.5396 & .58859 & .09192 \\
\cline { 2 - 6 } & Female & 49 & 3.3291 & .64180 & .09169 \\
\hline \multirow{2}{*}{ Sentiments } & Male & 41 & 3.7054 & .69100 & .10792 \\
\cline { 2 - 6 } & Female & 49 & 3.4019 & .56902 & .08129 \\
\hline
\end{tabular}

Source: Author's analysis 
ToSEE - Tourism in Southern and Eastern Europe, Vol. 5, pp. 335-348, 2019

S. Ivanović, A. Milenkovska Klimoska, V. Milojica: MEASURING SATISFACTION AND ...

Table 6: Independent Samples t-test

\begin{tabular}{|l|l|r|r|r|r|r|}
\hline \multicolumn{2}{|c|}{} & \multicolumn{2}{|c|}{$\begin{array}{l}\text { Levene's Test for } \\
\text { Equality of } \\
\text { Variances }\end{array}$} & \multicolumn{2}{|c|}{ t-test for Equality of Means } \\
\cline { 3 - 7 } & \multicolumn{1}{c|}{$\mathrm{F}$} & \multicolumn{1}{c|}{ Sig. } & \multicolumn{1}{c|}{$\mathrm{t}$} & $\mathrm{df}$ & $\begin{array}{l}\text { Sig. (2- } \\
\text { tailed) }\end{array}$ \\
\hline \multirow{2}{*}{$\begin{array}{l}\text { Satisfaction with } \\
\text { the Texts }\end{array}$} & $\begin{array}{l}\text { Equal variances } \\
\text { assumed }\end{array}$ & .004 & .950 & 1.609 & 88 & $\mathbf{. 1 1 1}$ \\
\cline { 2 - 7 } & $\begin{array}{l}\text { Equal variances not } \\
\text { assumed }\end{array}$ & & & 1.622 & 87.231 & .108 \\
\hline \multirow{3}{*}{ Sentiments } & $\begin{array}{l}\text { Equal variances } \\
\text { assumed }\end{array}$ & 3.024 & .086 & 2.286 & 88 & $\mathbf{. 0 2 5}$ \\
\cline { 2 - 7 } & $\begin{array}{l}\text { Equal variances not } \\
\text { assumed }\end{array}$ & & & 2.247 & 77.482 & .027 \\
\hline
\end{tabular}

Source: Author's analysis

If we observe the value of significance for the sentiments in the table presenting the Ttest results, it can be noticed that the significance of a test amounts less than 0.05 $(\mathrm{p}<0.05)$, respectively $\mathrm{p}=0.025$, due to which it can be stated that there is a statistically significant difference with sentiments considering the respondent's gender; the data in the table 5 indicate that average replies of male respondents for sentiments amount 3.7054, while the replies for female respondents amount approximately 3.4019 , meaning that the male respondents provided more replies for sentiments. Hypothesis 3 has been confirmed. By testing the hypothesis 2 it has been determined that there is no significant difference among respondents according to the gender in the terms of expressing high level of satisfaction with the texts $(\mathrm{p}>0.05)$, due to which this hypothesis is being rejected.

\section{CONCLUSION}

The main aim of this paper was to emphasize the importance of determining the attitudes of website users towards texts presenting the Croatian gastronomic tourist offer, respectively their level of satisfaction and its reflection on experienced sentiments after browsing, in order to determine whether potential improvements are necessary. The results clearly present the attitudes of the website users, respectively their level of satisfaction and which sentiments were expressed after browsing, which enabled determining advantages and lacks, based on which future improvements need to be made. By confirming the $\mathrm{H} 1$ the authors managed to determine that website users who experience higher level of satisfaction with the texts presenting the Croatian gastronomic offer will experience positive sentiments towards Croatia as a tourist destination, which is significant when choosing a holiday destination. $\mathrm{H} 2$ and $\mathrm{H} 4$ were rejected since no statistically significant difference has been determined for satisfaction in relation to gender or monthly income. $\mathrm{H} 3$ has been confirmed due to the presence of significant difference among male and female respondents in experiencing positive sentiments after browsing the texts. The results of this research contribute towards better understanding of importance of measuring satisfaction of website users with the texts presenting the (gastronomic) tourist offer, and experienced sentiments, which is indeed significant in a 
ToSEE - Tourism in Southern and Eastern Europe, Vol. 5, pp. 335-348, 2019

S. Ivanović, A. Milenkovska Klimoska, V. Milojica: MEASURING SATISFACTION AND

decision-making process when deciding where to spend their holiday and experiencing (gastronomic) tourist offer. As a limitation of this paper the authors need to mention that the results are based on a small statistical sample, due to which in the future this research will be repeated on a bigger number of respondents.

\section{ACKNOWLEDGEMENTS}

This paper has been prepared as a part of a scientific project titled "Croatia as a virtual tourist destination: a linguistic and sentiment analysis", project code ZP UNIRI 6/17, financed by the University of Rijeka.

\section{REFERENCES}

Agarwal B. and Mittal, N. (2014a), "Prominent feature extraction for review analysis: an empirical study", Journal of Experimental \& Theoretical Artificial Intelligence, Vol. 28, No. 3, pp. 485-498 https://doi:10.1080/0952813X.2014.977830

Agarwal, B. and Mittal, N. (2014b), "Semantic feature clustering for sentiment analysis of English reviews", IETE Journal of Research, Vol. 60, No. 6, pp. 414-422 https://doi.org/10.1080/03772063.2014.963172

Agarwal, B. and Mittal, N. (2015), Prominent Feature Extraction for Sentiment Analysis, Springer International Publishing, Switzerland.

Avelini Holjevac, I., Marković, S. and Raspor, S. (2009), "Customer satisfaction measurement in hote industry: Content analysis study", in Proceedings of 4th International Scientific Conference "Planning for the future learning from the past: Contemporary Developments in Tourism, Travel \& Hospitality", April 3-5, 2009, pp. 1-10, Rhones Islands, Greece.

Correia, A., Kozak, M. and Ferradeira J. (2013), "From tourist motivations to tourist satisfaction", International Journal of Culture, Tourism and Hospitality Research, Vol. 7, No. 4, pp. 411-424 https://doi.org/10.1108/IJCTHR-05-2012-0022

Dickinger, A. and Stangl, B. (2013), "Website performance and behavioral consequences: A formative measurement approach", Journal of Business Research, Vol. 66, No. 6, pp. 771-777 https://doi.org/10.1016/j.jbusres.2011.09.017

Foukis, A. (2015), "The Impact of Travel Website Characteristics on Consumers' Attitude Towards Intention to Purchase and Recommend", Master of Science Thesis, Network for Studies on Pensions, Aging and Retirement Netspar.

Gnoth, J., Zins A.H., Lengmueller, R. and Boshoff, Ch. (2000), "Emotions, Mood, Flow and Motivations to Travel", Journal of Travel \& Tourism Marketing, Vol. 9, No. 3, pp. 23-34 https://doi: 10.1300/J073v09n03 02

Gräbner, D., Zanker, M., Fliedl. G. and Fuchs, M. (2012), "Classification of Customer Reviews based on Sentiment Analysis". In Proceedings of the International Conference Information and Communication Technologies in Tourism, January 25-27, pp. 460-470, Helsingborg, Sweden.

Hasan, L. and Abuelrub, E. (2011), "Assessing the quality of web sites", Applied Computing and Informatics, Vol. 9, No. 1, pp. 11-29.

Ho, C-I and Lee, Y-L. (2007), "The development of an e-travel service quality scale", Tourism Management, Vol. 28, pp. 1434-1449.

Holtgräfe, C. and Zentes, J. (2012), "Multifaceted determinants of online non-prescription drug information seeking and the impact on consumers' use of purchase channels", Health Informatics Journal, Vol. 18, No. 2, pp. 95-110 https://doi.org/10.1177\%2F1460458212439487

Hosany, H., Prayag, G., Deesilatham, S., Causevic, S. and Odeh, K. (2014), "Measuring Tourists' Emotional Experiences: Further Validation of the Destination Emotion Scale", Journal of Travel Research, Vol. 54, No. 4, pp. 1-14. https://doi.org/10.1177/0047287514522878

Hosany, S. (2012), "Appraisal Determinants of Tourist Emotional Responses", Journal of Travel Research, Vol. 51, No. 3, pp. 303-314 https://doi.org/10.1177\%2F0047287511410320

Hosany, S. and Gilbert, D. (2009), "Measuring Tourists' Emotional Experiences toward Hedonic Holiday Destinations", Journal of Travel Research, Vol. 49, No. 4, pp. 513-526 https://doi.org/10.1177\%2F0047287509349267 
ToSEE - Tourism in Southern and Eastern Europe, Vol. 5, pp. 335-348, 2019

S. Ivanović, A. Milenkovska Klimoska, V. Milojica: MEASURING SATISFACTION AND

Ivanović, S. and Milojica, V. (2018), "Determining the Sentiments of Tourists towards Websites Text Contents of the Croatian Health Tourist Offer". In Proceedings of 24th Biennial International Congress Tourism \& Hospitality Industry 2018 Trends and Challenges, April 26-27, pp. 152-166, Opatija, Croatia

Kozak, M. (2001), "Repeaters' behaviour at two distinct destinations", Annals of Tourism Research, Vol. 28, No. 3, pp. 784-807 https://doi.org/10.1016/S0160-7383(00)00078-5

Kozak, M. and Rimmington, M. (2000), "Tourist Satisfaction with Mallorca, Spain, as an Off-Season Holiday Destination", Journal of Travel Research, Vol. 38, No. 3, pp. 260-269 https://doi.org/10.1177\%2F004728750003800308

Kozak, M., Bigne, E. and Andreu, L. (2005), "Satisfaction and Destination Loyalty: A Comparison between Non-repeat and Repeat Tourists", Journal of Quality Assurance in Hospitality and Tourism, Vol. 5 , No. 1, pp. 43-59 https://doi.org/10.1300/J162v05n01_04

Lapidus, M. and Bond-Dryankova, I. (2014), "Free drug information resources on the internet", Journal of Consumer Health on the Internet, Vol. 18, No. 4, pp. 367-376 https://doi.org/10.1080/15398285.2014.958936

Law, R., Qi, S. and Buhalis, D. (2010), "Progress in tourism management: A review of website evaluation in tourism research", Tourism Management, Vol. 31, No. 3, pp. 297-313 https://doi.org/10.1016/j.tourman.2009.11.007

Lin, H-F. (2007) The Impact of Website Quality Dimensions on Customer Satisfaction in the B2C E-commerce Context, Total Quality Management \& Business Excellence, Vol. 18, No. 4, pp. 363-378 DOI: $10.1080 / 14783360701231302$

Liu, Y., Huang, K., Bao, J. and Chen, K. (2019), "Listen to the voices from home: An analysis of Chinese tourists'sentiments regarding Australian destinations", Tourism Management, Vol. 71, pp. 337-347 https://doi.org/10.1016/j.tourman.2018.10.004

Lončarić, D., Lončarić, D. and Marković, S. (2015), "Health tourism, customer satisfaction and quality of life: The role of specialty hospitals". In Proceedings of $3^{\text {rd }}$ International Scientific Conference ToSEE Tourism in Southern and Eastern Europe 2015 Sustainable Tourism, Economic Development and Quality Life, May 13-16, pp. 159-173, Opatija, Croatia.

Maditinos, D., Mitsinis, N. and Sotidiadou, D. (2009), "Measuring User Satisfaction with Respect to Websites", Zagreb International Review of Economics \& Business, Vol. SCI, No. 1, pp. 81-97 https://hrcak.srce.hr/78670

Marković, S., Lončarić, D. and Lončarić, D. (2014), "Service Quality and Customer Satisfaction in the Health Care Industry-Towards Health Tourism Market", Tourism and hospitality management, Vol. 20, No. 2, 155-170 https://hrcak.srce.hr/130802

Marković, S., Raspor, S. and Kulašin, Dž. (2010), "Zadovoljstvo klijenta u hotelskoj industriji: koncept mjerenje" [Customer satisfaction in hospitality industry: concept and measurement], Univerzitetska hronika - časopis Univerziteta u Travniku, Vol. 2, No. 2, pp. 141-149.

Masa'deh, R., Al-Badi, A., Abu-Hlalah, A., Alkyal, R. and Zytoon, S. (2017), "Factors Affecting User's Satisfaction of Tourism Board Website and Its Impact on Continuous Intention to Use", International Journal of Business Administration, Vol. 8, No. 4, pp. 1-15 https://doi.org/10.5430/ijba.v8n4p1

Maxham III, J. G., and Netemeyer, R. G. (2003), "Firms reap what they sow: the effects of shared values and perceived organizational justice on customers' evaluations of complaint handling", Journal of Marketing, Vol. 67, No. 1, pp. 46-62 https://doi.org/10.1509/jmkg.67.1.46.18591

Maxham J. G. and Netemeyer, R. G. (2002a), "A longitudinal study of complaining customers' evaluations of multiple service failures and recovery efforts", Journal of Marketing, Vol. 66, No. 4, pp. 57-71 https://doi.org/10.1509/jmkg.66.4.57.18512

Maxham, J. G. and Netemeyer, R. G. (2002b), "Modeling customer perceptions of complaint handling over time: the effects of perceived justice on satisfaction and intent", Journal of retailing, Vol. 78, No. 4, pp. 239-252 https://doi.org/10.1016/S0022-4359(02)00100-8

Montoya-Weiss, M. M., Voss, G. B., and Grewal, D. (2003), "Determinants of online channel use and overall satisfaction with a relational, multichannel service provider", Journal of the Academy of Marketing Science, Vol. 31, No. 4, pp. 448-458.

Noronha, A.K. and Rao, P.S. (2017), "Effect of Website Quality on Customer Satisfaction and Purchase Intention in Online Travel Ticket Booking Websites", Management, Vol. 7, No. 5, pp. 168-173 https:// doi: 10.5923/j.mm.20170705.02

Oxford Economics, 2016, Mapping-the-future-of-global-travel-and-tourism, viewed 02 January 2019, https://www.oxfordeconomics.com/recent-releases/Mapping-the-future-of-global-travel-andtourism 
ToSEE - Tourism in Southern and Eastern Europe, Vol. 5, pp. 335-348, 2019

S. Ivanović, A. Milenkovska Klimoska, V. Milojica: MEASURING SATISFACTION AND ...

Pereira, H.G., Salgueiro, M.D. and Rita, P. (2017), "Online determinants of e-customer satisfaction: application to website purchases in tourism", Service Business, Vol. 11, No. 2, pp. 375-403 https://doi.org/10.1007/s11628-016-0313-6

Pilepić, Lj., Milojica, V. and Drpić, D. E-marketing in function of achieving competitiveness in Hospitality Industry. In Proceedings of COMBI 2010: Contemporary Views on Business: Partnering for the future, October 7-10, 2010, pp. 333, Vantaa, Finland.

Prayag, G., Sameer, H., Muskar, B. and Del Chiappa, G. (2015), "Understanding the Relationships between Tourists' Emotional Experiences, Perceived Overall Image, Satisfaction, and Intention to Recommend", Journal of Travel Research, Vol. 56, No. 1, pp. 41-54 https://doi.org/10.1177\%2F0047287515620567

Rahmani, K., Gnoth, J. and Mather, D. (2018), "A Psycholinguistic View of Tourists' Emotional Experiences", Journal of Travel Research, Vol. 58, No. 2, pp. 192-206, https://doi.org/10.1177/0047287517753072

Richards, G. (2012), "An overview of food and tourism trends and policies". In Food and the Tourism Experience: The OECD-Korea Workshop, OECD Studies on Tourism, OECD Publishing, pp. 13$43 \mathrm{http}: / /$ dx.doi.org/10.1787/9789264171923-en

Roblek, V., Pejić Bach, M., Meško, M., and Bertoncelj, A. (2018), "To click or to buy over the counter drugs: exploring the behaviour of Slovenian customers", International Journal of Electronic Marketing and Retailing, Vol. 9, No. 2, pp. 145-166 https://doi.org/10.1504/IJEMR.2018.090890

RuelNovabos, C., Matias, A. and Mena, M. (2015), "How Good is this Destination Website: A User-centered Evaluation of Provincial Tourism Websites", Procedia Manufacturing, Vol. 3, pp. 3478-3485.

Servidio, R. and Ruffolo, I. (2016), "Exploring the relationship between emotions and memorable tourism experiences through narratives", Tourism Management Perspectives, Vol. 20, pp. 151-160 https://doi.org/10.1016/j.tmp.2016.07.010

Sigala, M. (2011), "Evaluating Website Design and Structure in Tourism: Dimensions, Stakeholders and Marketing Issues", Journal of Hospitality Marketing \& Management, Vol. 20, No. 7, pp. 691-694, https://doi: 10.1080/19368623.2011.577702

Subramonian, H., Hussain, K. and Haddad, F. (2014), "Determinants of e-Satisfaction of Travel Websites in China", Tourism Development Journal, Vol. 11-12, No. 1, pp. 1-18.

Tourism Economics (2017), The Impact of Online Content on European Tourism-an Update (July 2017), viewed 02 February 2019, https://www.oxfordeconomics.com/recent-releases/the-impact-ofonline-content-on-european-tourism

Tsai, S-p. (2017), "E-loyalty driven by website quality: The case of destination marketing organization websites", Journal of Organizational Computing and Electronic Commerce, Vol. 27, No. 3, pp. 262-279.

Yan, Q., Zhou, S. and Wu, S. (2018), "The influences of tourists' emotions on the selection of electronic word of mouth platforms", Tourism Management, Vol. 66, pp. 348-363 https://doi.org/10.1016/j.tourman.2017.12.015

Yoo, B., and Donthu, N. (2001), "Developing and validating a multidimensional consumer-based brand equity scale", Journal of business research, Vol. 52, No. 1, pp. 1-14 https://doi.org/10.1016/S0148-2963(99)00098-3 
ToSEE - Tourism in Southern and Eastern Europe, Vol. 5, pp. 335-348, 2019

S. Ivanović, A. Milenkovska Klimoska, V. Milojica: MEASURING SATISFACTION AND

Slobodan Ivanović, PhD, Full Professor with Tenure

University of Rijeka

Faculty of Tourism and Hospitality Management

Department of Hospitality, Gastronomy and Restaurant Business

Primorska 42, Opatija, Republic of Croatia

Phone: +385 51 294-752

E-mail: sivanov@fthm.hr

Angela Milenkovska Klimoska, MA., PhD Student, Teaching Assistant

University of Tourism and Management Skopje

Department of Marketing

Partizanski odredi Boulevard 99, Skopje Northern Macedonia

Phone: +38975 464631

E-mail: a.milenkovskaklimoska@utms.edu.mk

Vedran Milojica, MA., PhD Student

University of Rijeka

Faculty of Tourism and Hospitality Management

Primorska 42, Opatija, Republic of Croatia

E-mail: vedran.milojica@gmail.com 